\title{
ETIKA PENYUSUNAN LAPORAN KEUANGAN DALAM MENINGKATKAN KUALITAS LAPORAN KEUANGAN; DITINJAU DARI PERSPEKTIF ISLAM
}

\author{
Siti Asiam \\ Jurusan Syariah dan Ekonomi Islam, Sekolah Tinggi Agama Islam Negeri (STAIN) Bengkalis \\ Email : asiam@kampusmelayu.ac.id
}

\begin{abstract}
ABSTRAK
Penelitian ini dilatarbelakangi oleh banyaknya kasus kecurangan dalam pelaporan keuangan yang disebabkan oleh kurangnya etika dalam penyusunan laporan keuangan. Tujuan penelitian ini adalah untuk mengkonstruksi etika penyusunan laporan keuangan dalam meningkatkan kualitas laporan keuangan dalam tinjauan perspektif Islam. Perspektif Islam yang digunakan dalam penelitian ini adalah perspektif tokoh Islam dari Indonesia yaitu Abdurrahman Wahid (Gus Dur), perspektif tokoh Islam digunakan untuk menemukan teori yang berdasarkan kearifan lokal. Penelitian ini merupakan penelitian kepustakaan (library research) sehingga data diperoleh melalui proses studi literatur. Hasil penelitian ini menunjukkan bahwa dalam perspektif Abdurrahman Wahid, etis atau tidaknya sebuah tindakan bukan hanya berdasarkan manfaat dan kewajiban, tetapi harus berlandaskan keadilan. Keadilan yang dimaksud adalah keadilan yang memberikan maslahat bagi semua pihak, yang dalam hal ini adalah pihak internal dan eksternal dari sebuah entitas. Sehingga etika dalam penyusunan laporan tidak boleh hanya bertujuan untuk memberikan keuntungan bagi pihak internal, tetapi juga harus memberikan keuntungan bagi pihak eksternal dengan memberikan laporan yang adil. Hal ini bertujuan agar kualitas laporan keuangan meningkat sehingga informasi yang tersajikan tidak merugikan pihak manapun. Penelitian selanjutnya diharapkan mengunakan bahan kajian yang lebih komprehensif, sehingga hasil penelitian bisa lebih detail.
\end{abstract}

Kata kunci : Etika, Laporan Keuangan, Kualitas, Keadilan.

\begin{abstract}
This research is motivated by the many cases of fraud in financial reporting that caused by a lack of ethics in the financial statements reporting. This research has purpose to construct the ethics of preparing financial statements in improving the quality of financial reports from an Islamic perspective. The Islamic perspective that used is the perspective figure from Indonesia, Abdurrahman Wahid (Gus Dur), the perspective of Islamic figures is used to find theories based on local wisdom. This research is a library research so that data is obtained through the process of studying the literature. The results of this study indicate that in Abdurrahman Wahid's perspective, whether or not an action is ethical is not only based on benefits and obligations, but must be based on justice. Justice here has substance that provides benefits to all parties, which in this case are internal and external parties of an entity. So that ethics in preparing financial reports should not only aim to provide benefits to internal parties, but also must provide benefits to external parties by providing fair reports. This is intended for the quality of the financial statements so that the information that presented give true information to all parties. The next researcher expected to use more comprehensive theory. So that the research results can be more detailed.
\end{abstract}

Keywords : Ethics, Financial Statements, Quality, Fairness. 


\section{PENDAHULUAN}

Bagi pihak-pihak yang berkepentingan, laporan keuangan merupakan sebuah alat yang dapat menjadi media informasi keuangan perusahaan. Hal ini selaras dengan tujuan laporan keuangan yaitu guna memberikan informasi yang bermanfaat untuk para investor dan kreditur serta investor maupun kreditur yang memiliki potensi dalam pembuatan keputusan yang rasional. Bagi pihak manajemen, laporan keuangan digunakan oleh manajemen sebagai bentuk pertanggungjawaban perusahaan atas penggunaan sumber daya yang dipercayakan kepada perusahaan.

Informasi akuntansi dikatakan
berkualitas jika informasi rersebut
memenuhi dua karakteritik kualitatif
fundamental, yaitu relevan dan tersaji
secara jujur. Informasi yang relavan
apabila informasi tersebut memiliki nilai
prediksi, serta nilai konfirmasi. Informasi
memiliki nilai prediksi jika informasi
tersebut dapat dijadikan acuan dalam
pembuatan keputusan di masa datang
berdasarkan kejadian masa lalu.

Laporan keuangan memiliki peran yang sangat penting bagi pengguna internal dan eksternal. Pentingmya laporan keuangan menuntut penyajian laporan keuangan yang baik dan benar. Namun yang sebaliknya terjadi adalah tidak semua entitas bisnis menyajiakan laporan keuangan secara benar dan sesuai dengan kondisi keuangan yang sebenarnya.

Kecurangan dalam proses pelaporan keuangan terbesar yang berhasil terkuak adalah kasus Enron. Enron berdiri pada tahun 1985 yang merupakan perusahaan dari penggabungan antara Inter North (penyalur gas alam melalui pipa) dengan Houston Natural Gas. Perusahaan ini terus berkembang sehingga menjadi perusahaan yang menduduki ranking tujuh dari lima ratus perusahaan terkemuka di Amerika Serikat dan merupakan perusahaan energi terbesar di AS. Namun pada tahun 2002 perusahaan tersebut jatuh bangkrut dengan meninggalkan hutang hampir sebesar US \$31.2 milyar. Kasus ini terjadi karena dilakukannya manipulasi laporan keuangan dengan mencatat keuntungan 600 juta Dollar AS padahal perusahaan mengalami kerugian. Manipulasi keuntungan ini dilakukan dengan tujuan untuk menarik minat investor ini menjadi petaka yang justru mengantar perusahaan ke jurang kebangkrutan.

Di Indonesia kasus kecurangan dalam pelaporan keuangan juga sering terjadi. Contoh kasus kecurangan dalam pelaporan keuangan skala nasional adalah laporan keuangan ganda entitas bisnis Lippo tahun 2002, kasus PT. Muzatek Jaya 2004, kasus PT. KAI 2006, dan kasus kredit macet BRI Cabang Jambi 2010.

Kecurangan tersebut terjadi karena beberapa faktor. Berdasarkan Wolfe dan Hermanson (2004), faktor-faktor pendorong terjadinya kecurangan adalah: Pertama, pressure (tekanan) merupakan motivasi yang dapat mengerakkan seseorang untuk melakukan tindakan fraud. Kedua, Opportunity (peluang) merupakan situasi yang memberikan kesempatan seseorang melakukan kecurangan. Ketiga, Rationalization (rasionalisasi) merupakan pembenaran atas perbuatan yang dilakukan. Keempat, capability (kemampuan) merupakan kapasitas sesorang yang mendorong seseorang untuk melakukan fraud.

Kecurangan tersebut tentunya dapat diminimalisir dengan menerapkan aturan dan pribadi yang Islami. Hal ini karena perilaku dan lingkungan Islam berpengaruh terhadap kepatuhan sistem pengendalian internal dalam mencegah niat melakukan Kecurangan (Irvan dan Aisyah, 2018). 
Dalam konteks Indonesia, maka Indonesia belum memiliki teori akuntansi sendiri dan masih menggunakan teori akuntansi Barat sebagai dasar pengembangan akuntansi. Belkaoui menganjurkan agar setiap negara memiliki teori akuntansinya sendiri, hal ini karena pada dasarnya teori akuntansi lahir dari kondisi, lingkungan, situasi ekonomi, dan situasi sosial yang ada pada suatu negara dan akan berbeda dengan negara lainnya (Irvan dan Aisyah, 2018).

Formulasi teori akuntansi Indonesia yang digali dari kondisi Keindonesiaan merupakan hal ideal yang tidak mungkin dapat diwujudkan dalam jangka pendek, namun demikian pada dasarnya kita harus menuju kesana. Dalam hal ini maka perlu peran dari profesi dan pemerintah agar upaya ini segera akan berjalan dan terwujud (Harahap, 1993).

Untuk membangun teori akuntansi yang membawa nilai Keindonesiaan, maka perlu penggalian terhadap kearifan lokal. Kearifan lokal merupakan strategi adaptasi yang muncul dari dalam masyarakat sebagai upaya untuk membenahi masalah-masalah sosial yang berkenaan dengan masyarakat itu sendiri (Saharuddin, 2009). Kearifan lokal merupakan hasil interaksi antara masyarakat dengan lingkungannya sehingga menjadi inti dari usaha mengentaskan kemiskinan yang ada dan tumbuh didalam masyarakat (Wagiran, 2011).

Dalam penelitian ini, etika penyusunan laporan keuangan dilakukan dengan alat analisis kearifan lokal Keindonesiaan. Kearifan lokal yang digunakan dalam penelitian ini diambil dari pemikiran ekonomi Gus Dur. Pemilihan pemikiran ekonomi Gus Dur sebagai alat analisis didasari oleh beberapa alasan. Pertimbangan pertama adalah Gus Dur merupakan seorang tokoh besar bagi bangsa Indonesia yang memiliki filosofi hidup yang mementingkan asas manfaat yang diambil dari ajaran Islam (Isre, 1998). Selanjutnya dalam bidang ekonomi Gus Dur banyak menyumbangkan pemikiran dan gerakan. Pemikiran dan gerakan tersebut tertuang dalam sebuah prinsip utama yang ingin dicapai, yaitu keadilan (Saharuddin, 2009).

\section{TINJAUAN PUSTAKA}

\section{Etika Penyusunan Laporan Keuangan}

Laporan keuangan disusun oleh akuntan internal dengan tujuan untuk memberikan informasi kepada pihakpihak yang berkepentingan. Informasi yang tercantum pada laporan keuangan ini akan diaudit oleh akuntan publik sebelum digunakan oleh pihak-pihak yang berkepentingan dalam mengambil keputusan.

Fungsi laporan keuangan yang penting tentunya menuntut kualitas yang baik. Kualitas laporan keuangan secara tidak langsung akan menentukan ketepatan dalam pengambilan keputusan. Keputusan yang tepat akan mempengaruhi kesuksesan pihak-pihak terkait.

Perbedaan kepentingan terhadap laporan keuangan akan mempengaruhi kualitas laporan keuangan, karena keserakahan individu dan korporasi, independensi yang rendah, dan menghindari aturan merupakan kelemahan yang terdapat pada akuntan (Wyatt, 2004).

Perbedaan kepentingan dan sikap profesionalitas dalam diri akuntan memerlukan sebuah standar etis yang akan memandu dan mengharuskan akuntan untuk berlaku sesuai dengan ketentuan. Etika merupakan prinsip nilai yang berperan menentukan apa yang harus dilakukan atau tidak boleh dilakukan oleh seorang individu, sehingga etika merupakan bidang ilmu yang bersifat normatif (Beekum, 2004). 
Di Indonesia, kode etik akuntan telah dirumuskan oleh Ikatan Akuntan Indonesia (IAI). Berdasarkan kode etik akuntan ini, akuntan profesional harus mematuhi prinsip dasar etika berikut ini :

a) Integritas, yaitu bersikap lugas dan jujur dalam semua hubungan profesional dan bisnis.

b) Objektivitas, yaitu tidak membiarkan bias, benturan kepentingan, atau pengaruh yang tidak semestinya dari pihak lain, yang dapat mengesampingkan pertimbangan profesional atau bisnis.

c) Kompetensi dan kehati-hatian profesional, yaitu menjaga pengetahuan dan keahlian profesional pada tingkat yang dibutuhkan untuk memastikan bahwa klien atau pemberi kerja akan menerima jasa profesional yang kompeten berdasarkan perkembangan praktik, peraturan, dan teknik mutakhir, serta bertindak sungguh-sungguh dan sesuai dengan teknik dan standar profesional yang berlaku.

d) Kerahasiaan, yaitu menghormati kerahasiaan informasi yang diperoleh dari hasil hubungan profesional dan bisnis dengan tidak mengungkapkan informasi tersebut kepada pihak ketiga tanpa ada kewenangan yang jelas dan memadai, kecuali terdapat suatu hak atau kewajiban hukum atau profesional untuk mengungkapkannya, serta tidak menggunakan informasi tersebut untuk keuntungan pribadi Akuntan Profesional atau pihak ketiga.

e) Perilaku Profesional, yaitu mematuhi hukum dan peraturan yang berlaku dan menghindari perilaku apa pun yang mengurangi kepercayaan kepada profesi Akuntan Profesional.

\section{Kualitas Laporan Keuangan}

Islam telah memerintahkan setiap muslim untuk malakukan pencatatan terhadap sesuatu transaksi yang dilakukan tidak secara tunai. Salah satu ayat AlQuran yang menegaskan tentang pencatatan adalah Q.S Al-Baqarah: 282. Menurut Ibnu Katsir dalam tafsirnya, ayat ini menjelaskan tentang pentingnya pencatatan utang piutang. Lebih lanjut dijelaskan bahwa tujuan dilakukan pencatatan adalah untuk memperkuat dan memelihara (Ad-Dimasyqi, 2005).

Karakteristik kualitatif fundamental yang harus dimuat agar informasi dalam laporan keuangan menjadi berguna adalah relevansi, materialitas, representasi tepat, dan penerapan karakteristik kualitatif fundamental. Laporan keuangan berkualitas harus empat karakteristik kualitatif pokok laporan keuangan memiliki, yakni: (1). Dapat Dipahami, laporan keuangan harus memuat Informasi yang berkualitas, yaitu informasi yang dengan mudah dan segera dapat dipahami oleh pemakainya. (2). Relevan, Informasi dalam laporan keuangan dikatakan relevan jika dapat mempengaruhi keputusan ekonomi pemakainya, dalam hal ini relevansi informasi bermanfaat dalam peramalan dan penegasan. (3). Keandalan, Informasi laporan keuangan dikatakan memiliki kualitas andal apabila bebas dari pengertian yang menyesatkan, kesalahan material dan dapat diandalkan pemakainya sebagai penyajian yang tulus/jujur dari yang seharusnya disajikan atau yang secara wajar diharapkan dapat disajikan. (4). Dapat dibandingkan, laporan keungan harus dapat dibandingkan dengan laporan Keuangan perusahaan antarperiode untuk mengidentifikasi kecenderungan posisi dan kinerja perusahaan. 


\section{METODE PENELITIAN}

Penelitian ini menggunakan metode kualitatif. Penelitian kualitatif adalah prosedur penelitian yang menghasilkan data deskriptif berupa katakata tertulis atau lisan dari orang-orang dan perilaku yang dapat diamati, didukung oleh studi literatur dan studi kepustakaan berdasarkan pada pendalaman kajian, pustaka, berupa data dan angka, sehingga realitas dapat dipahami dengan baik (Moleong, 2004).

Penelitian ini merupakan jenis penelitian kepustakaan (library research), di mana data-data yang dipakai adalah data kepustakaan. Didalam penelitian ini, analisis data didasarkan pada perspektif Gus Dur dalam melihat suatu permasalahan. Sebagai pemimpin NU tentu saja paham Gus Dur dilandasakan pada sumber ajaran Islam yang berupa AlQuran, Hadits, Ijma', dan Qiyas.

\section{HASIL DAN PEMBAHASAN}

\section{Teori Keadilan dalam Perspektif Abdurrahman Wahid}

Abdurrahman Wahid atau yang lebih akrab disapa Gus Dur lahir pada 4 Agustus 1940 di Denanyar Jombang dengan nama asli Abdurrahman AdDakhil. Secara genetik Abdurrahman Wahid adalah keturunan darah biru yang tergolong seorang santri dan priyayi sekaligus yang terlibat dalam pergolakan gerakan nasional dan Islam. Meskipun keturunan Kyai dan bangsawan Indonesia, kehidupan Gus Dur tidak mencerminkan kehidupan seorang ningrat tetapi berproses dan hidup sebagaimana layaknya masyarakat kebanyakan (Rahardjo, 2010).

Penelitian ini akan difokuskan kepada penelusuran pemikiran-pemikiran Gus Dur dalam bidang ekonomi. Pemilihan fokus terhadap pemikiran ekonomi bertujuan untuk memberikan batasan bahwa yang menjadi perhatian dalam penelitian ini adalah setiap pendapat maupun argumen yang menyangkut bidang ekonomi. Pemikiran ekonomi menjadi perhatian utama karena disesuaikan dengan konteks penelitian dalam bidang akuntansi.

Pemikiran Gus Dur dalam bidang ekonomi berangkat dari pandangan bahwa manusia adalah khalifah Allah SWT. Sebagai pemegang tugas khalifah di muka bumi maka manusia dibekali dengan berbagai kemampuan. Kemampuan tersebut diperlukan untuk digunakan sebagai penunjang manusia untuk memenuhi tugasnya sebagai khalifah. Pandangan Gus Dur dalam hal ini terdapat dalam kutipan berikut ini:

"Islam memberikan kemampuan fitri, akli, dan persepsi kejiwaan untuk membawakan kepada kita beberapa kewajiban yang tidak ringan. Kewajiban untuk senantiasa taat asas (konsisten) dalam berpikir dan mencari pemecahan bagi persoalan-persoalan yang kita hadapi, kewajiban menjunjung tinggi tujuan utama kehidupan menurut Islam (i.e. mencari kemaslahatan sejauh mungkin, menjauhkan kerusakan atau mafsadah sekuat mungkin, dan menerapkan asas kerahmatan dalam kehidupan secara keseluruhan), kewajiban menyediakan sarana yang diperlukan untuk pencapaian tujuan utama kehidupan di atas dan kewajiban memikul tanggung jawab penyelenggaraan kehidupan bermasyarakat secara tuntas dan jujur, itu semua adalah rangkaian kewajiban yang tidak dapat dilepaskan satu dari yang lain. Hanya dengan pelaksanaan semua kewajiban di atas secara simultan dan dalam kerangka upaya yang bersifat integral barulah dapat dipenuhi keseimbangan penanganan yang diperlukan untuk menangani 
kesulitan-kesulitan di masa kini dan menghadapi hari esok dengan tantangan-tantangan yang lebih berat lagi (Wahid, 1983).

Kutipan di atas memberikan gambaran bahwa tugas sebagai khalifah bukanlah merupakan sesuatu yang ringan. Oleh karena itu manusia dibekali dengan berbagai kemampuan oleh Allah SWT. Sebagai khalifah manusia harus konsisten dalam hal berpikir dan bertindak untuk mencari pemecahan masalah. Segala bentuk tindakan manusia harus menjunjung tinggi tujuan utama kehidupan menurut ajaran Islam, yaitu untuk mencari kemaslahatan dan menghindari kemudaratan sehingga akan mendapatkan rahmat secara menyeluruh. Kewajiban beserta batasan-batasan dalam melaksanakannya harus dilakukan secara konsisten dan tidak terpisah satu dengan lainnya. Sehingga segala permasalahan akan bisa diatasi, baik yang sedang dihadapi atau yang akan dihadapi pada masa yang mendatang.

Sebagai khalifah di muka bumi, maka manusia bertanggungjawab untuk menyelesaikan permasalahan hidup secara tuntas. Hal ini disampaikan Gus Dur sebagai berikut:

"Islam memberikan hak kepada manusia untuk menjadi "pengganti Allah SWT" (khalifah) di muka bumi, sebuah fungsi kemasyarakatan yang mengharuskan kaum muslimin untuk senantiasa memperjuangkan dan melestarikan cita hidup kemasyarakatan yang mampu mensejahterakan manusia itu sendiri secara menyeluruh dan tuntas. Dengan demikian kaum muslimin diharuskan untuk menentang pola kehidupan bermasyarakat yang eksploitatif, tidak manusiawi serta tidak berasaskan keadilan dalam artiannya yang mutlak (Wahid, 1983).
Kutipan di atas memberikan gambaran bahwa Gus Dur memahami peran manusia sebagai khalifah untuk selalu berjuang untuk mencapai kesejahteraan secara menyeluruh dan tuntas. Untuk mencapai kesejahteraan secara menyeluruh dan tuntas maka diperlukan pola hidup yang bebas dari segala bentuk eksploitasi. Selain itu juga diperlukan pola hidup yang manusiawi dengan tegaknya keadilan.

Dari pemaparan di atas bisa ditarik sebuah kesimpulan bahwa pemikiran ekonomi Gus Dur memiliki fokus untuk mensejahterakan seluruh rakyat dengan mewujudkan keadilan ekonomi yang bebas dari semua bentuk eksploitasi. Jika dikaitkan dengan perusahaan (khususnya kebijakan etika penyusunan laporan keuangan) maka sudah seharusnya memberikan substansi yang benar-benar adil dalam memberikan kesejahteraan bagi berbagai pihak.

Keadilan merupakan hal yang sangat ditekankan dalam ajaran Islam. Salah satu ayat Al-Quran yang sangat jelas memerintahkan keadilan adalah surat An Nahl ayat 90 sebagai berikut:

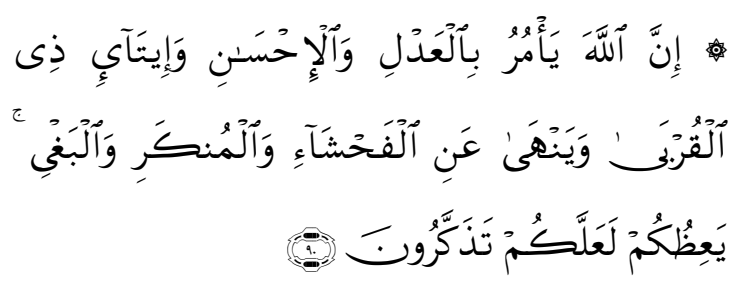

Artinya: "Sesungguhnya Allah menyuruh (kamu) Berlaku adil dan berbuat kebajikan, memberi kepada kaum kerabat, dan Allah melarang dari perbuatan keji, kemungkaran dan permusuhan. Dia memberi pengajaran kepadamu agar kamu dapat mengambil pelajaran" (Q.S. An Nahl ayat 90).

Berdasarkan hal di atas maka bisa diambil kesimpulan bahwa nilai keadilan dalam pemikiran Abdurrahman Wahid sangat erat kaitannya dengan nilai-nilai Islam yang terkandung dalam Al-Quran. 
Hal ini menjadi landasan bahwa nilai keadilan yang dalam pemikiran Abdurrahman Wahid merupakan nilai turunan yang diambil dari Al-Quran.

\section{Etika Penyusunan Laporan Keuangan Berdasarkan Perspektif Islam dalam Pemikiran Abdurrahman Wahid}

Sebagai bentuk pertanggung jawaban atas kepengurusan sumber daya ekonomi yang dimiliki oleh suatu entitas maka setiap entitas harus menyusun laporan keuangan. Agar laporan keuangan tersebut dapat dibandingkan dengan laporan keuangan periode sebelumnya atau dibandingkan dengan laporan keuangan entitas yang jelas laporan keuangan yang diterbitkan harus disusun sesuai dengan standar akuntansi yang berlaku.

Menyusun dan mengembangkan standar profesi dan kode etik profesi akuntan publik yang berkualitas dengan mengacu pada standar Internasional merupakan salah satu misi Institut Akuntan Publik Indonesia (IAPI). Untuk memenuhi hal ini maka IAPI telah memberikan tanggung jawab kepada Dewan Standar Profesional Akuntan Publik IAPI untuk mengembangkan dan menetapkan suatu standar profesi dan kode etik profesi yang berkualitas yang berlaku bagi profesi akuntan publik di Indonesia.

Gus Dur merupakan tokoh yang menolak kebijakan yang hanya menguntungkan sebagian pihak tanpa memperhatikan pihak lain. Hal ini diungkapkan sebagai berikut

"Skala prioritas garapan
pembangunan haruslah didasarkan
pada asas pengembangan, bukannya
asas pertumbuhan.
pengembangan berarti pilihan arah
dan orientasi pembangunan yang
menumbuhkan kekuatan sendiri untuk
memenuhi kebutuhan hidup dengan
kendali kokoh, bukannya asal

menumbuhkan kekuatan secara asal tumbuh saja. Karena hanya sekadar pemenuhan kebutuhan hidup saja yang dikejar, maka strategi pembangunan harus ditujukan kepada pemenuhan kebutuhan semua warga negara" (Wahid, 1983).

Walaupun pandangan di atas terkait dengan bidang ekonomi, tetapi hal tersebut bisa dijadikan referensi bahwa setiap perbuatan dan kebijakan harus memperhatikan dan menguntungkan setiap pihak. Sehingga manfaat dari adanya pelaporan keuangan akan dirasakan oleh warga negara secara keseluruhan bukan hanya untuk sebagian warga saja.

Manfaat yang bisa dirasakan oleh semua pihak merupakan wujud dari nilai keadilan. Keadilan disini pada dasarnya ditujukan bagi pihak-pihak yang kurang mendapatkan perhatian. Gus Dur merupakan tokoh yang sangat peduli terhadap wujudnya keadilan. Sebagaimana disampaikan berikut ini:

"Kesadaran untuk selalu memikirkan kepentingan bersama harus selalu dikembangkan, untuk memungkinkan tumbuhnya moralitas individual yang seperti itu, disamping untuk memungkinkan tumbuhnya etos sosial yang dinamis dan kreatif" (Wahid, 1983).

Kutipan di atas memberikan gambaran bahwa Gus Dur merupakan tokoh yang sangat peduli terhadap pihakpihak yang terpinggirkan. Sehingga dalam hal kebijakan atau pelaporan harus mengembangkan hal-hal yang bersifat kebersamaan.

Jika dilihat dari substansi etika penyusunan laporan keuangan hal ini akan sejalan dengan konsep kepentingan bersama. Etika penyusunan laporan keuangan yang sarat dengan nilai material sudah selayaknya dialihkan kepada tujuan 
yang juga sarat pada nilai-nilai yang non material.

Berbeda dengan paham kapitalis yang menganggap individu sebagai pemilik harta, sehingga segala tujuan kegiatan bisnis semata-mata hanya untuk meraih keuntungan materi saja. Dalam Islam, pemilik mutlak atas segala kekayaan di dunia adalah Allah SWT dan Allah SWT menciptakan segala sesuatunya untuk seluruh manusia (Triyuwono dan As'udi, 2001). Sehingga konsep kepemilikan dalam Islam berbeda dengan konsep kepemilikan sistem-sistem ekonomi lain (kapitalis, sosialis, komunis, dan lain-lain). Islam memberikan keseimbangan antara kepemilikan pribadi dengan menjamin pendistribusian yang seluas-luasnya kepada pihak-pihak yang berhak menerimanya (Triyuwono dan As'udi, 2001).

Kontruksi nilai keadilan dalam penyusunan laporan keuangan secara keseluruhan dapat disajikan dalam gambar berikut:

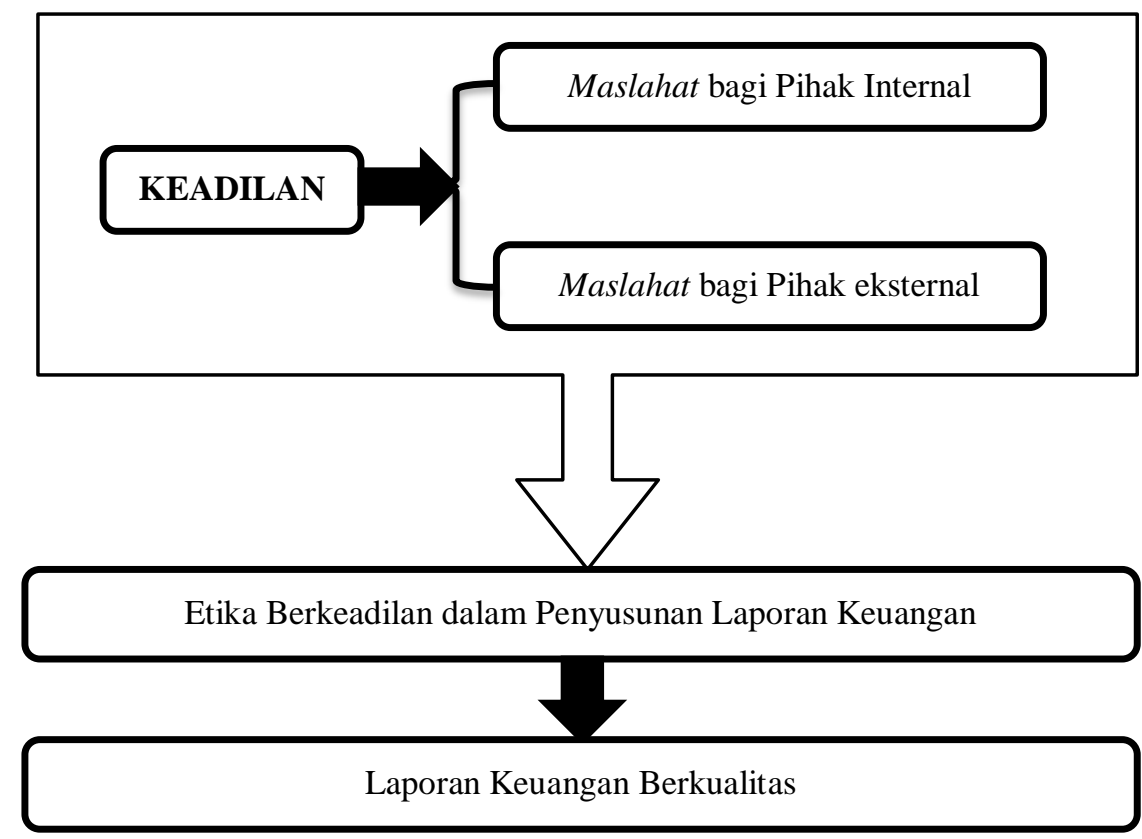

\section{Gambar 1. Konstruksi Etika Penyusunan Laporan Keuangan}

Dari pemaparan di atas dapat ditarik sebuah kesimpulan bahwa etika dalam penyusunan laporan tidak boleh hanya bertujuan untuk memberikan keuntungan bagi pihak internal, tetapi juga harus memberikan keuntungan bagi pihak eksternal. Hal ini bertujuan agar kualitas laporan keuangan meningkat sehingga informasi yang tersajikan tidak merugikan pihak manapun.

\section{KESIMPULAN}

Penelitian ini menyimpulkan bahwa etika penyusunan laporan keuangan dalam meningkatkan kualitas laporan keuangan dalam perspektif Islam dalam pemikiran Gus Dur menyatakan bahwa etis tidaknya sebuah tindakan bukan hanya berdasarkan manfaat, kewajiban, keadilan, atau keutamaan. Tindakan yang kita lakukan harus mengandung nilai keadilan. Keadilan yang dimaksud adalah keadilan yang memberikan maslahat bagi semua pihak, yang dalam hal ini adalah pihak internal dan eksternal dari sebuah entitas. Etika dalam penyusunan laporan tidak boleh hanya bertujuan untuk memberikan keuntungan bagi pihak internal, tetapi juga harus memberikan keuntungan bagi pihak 
eksternal. Hal ini bertujuan agar kualitas laporan keuangan meningkat sehingga informasi yang tersajikan tidak merugikan pihak manapun.

Penelitian ini memiliki keterbatasan karena hanya meneliti pendapat atau pandangan dari seorang tokoh. Bagi peneliti seanjutnya diharapkan mengunakan bahan kajian yang lebih komprehensif. Sehingga hasil penelitian bisa lebih detail.

\section{DAFTAR PUSTAKA}

Ad-Dimasyqi, Al-Imam Abul Fida Isma'il Ibnu Kasir. 2005. Terjemahan Tafsir Ibnu Kasir. Sinar Baru Algensindo. Bamdung.

Beekum, Rafik Issa. 2004. Etika Bisnis Islami. Pustaka Pelajar. Yogyakarta.

Harahap, S.S. 1993. Teori Akuntansi. Raja Grafindo Persada. Jakarta.

Irvan, Muhammad Alif Nur,. \& Aisyah, Maulidyati. 2018. Pencegahan Kecurangan (Fraud) Di Pondok Modern Gontor. Conference On Islamic Management, Accounting, and Economic.

Isre, M.S. 1998. Tabayun Gus Dur: Pribumisasi Islam, Hak Minoritas, Reformasi Kultural. LKiS Yogyakarta.

Moleong, J.L. 2004. Metodologi Penelitian Kualitatif. PT. Remaja Roksadakarya. Bandung.

Rahardjo, MD. 2010. Damai Bersama Gus Dur. KOMPAS. Jakarta.

Saharuddin. 2009. Perberdayaan Masyarakat Miskin Berbasis Kearifan Lokal. Jurnal: Sodality: Jurnal Transdisiplin Sosiologi, Komunikasi, dan Ekologi Manusia, 3(1). Avalaible Online at: http://download.portalgaruda.org/art icle.php?article $=83549 \& \mathrm{val}=223$.
Triyuwono, I. \& As'udi, Moh. 2001. Akuntansi Syari"Ah: Memformulasikan Konsep Laba dalam Konteks Metafora Zakat. Selemba Empat. Jakarta.

Wagiran. 2011. Pengembangan Model Pendidikan Kearifan Lokal dalam Mendukung Visi Pembangunan Provinsi Daerah Istimewa Yogyakarta 2020 (Tahun Kedua). Jurnal: Penelitian dan Pengembangan, 3(3). Avalaible Online at: http://staff.uny.ac.id/sites/default/fil es/penelitian/Wagiran,\%20S.Pd.,M. Pd.,\%20Dr./Pendidikan\%20kearifan $\%$ 20lokal.pdf.

Wahid A. 1983. Muslim di Tengah Pergumulan. Lembaga Penunjang Pembangunan Nasional (Leppenas). Jakarta.

Wolfe, David T., \& Hermanson, R. 2004. The Fraud Diamond: Considering the Four Elements of Fraud. CPA Journal 74.12, 38-42.

Wyatt, A.R. 2004. Accounting Profesionalism- They Just Don't Get It!. Accounting Horizons, Vol. 18, pp. 45-43. 